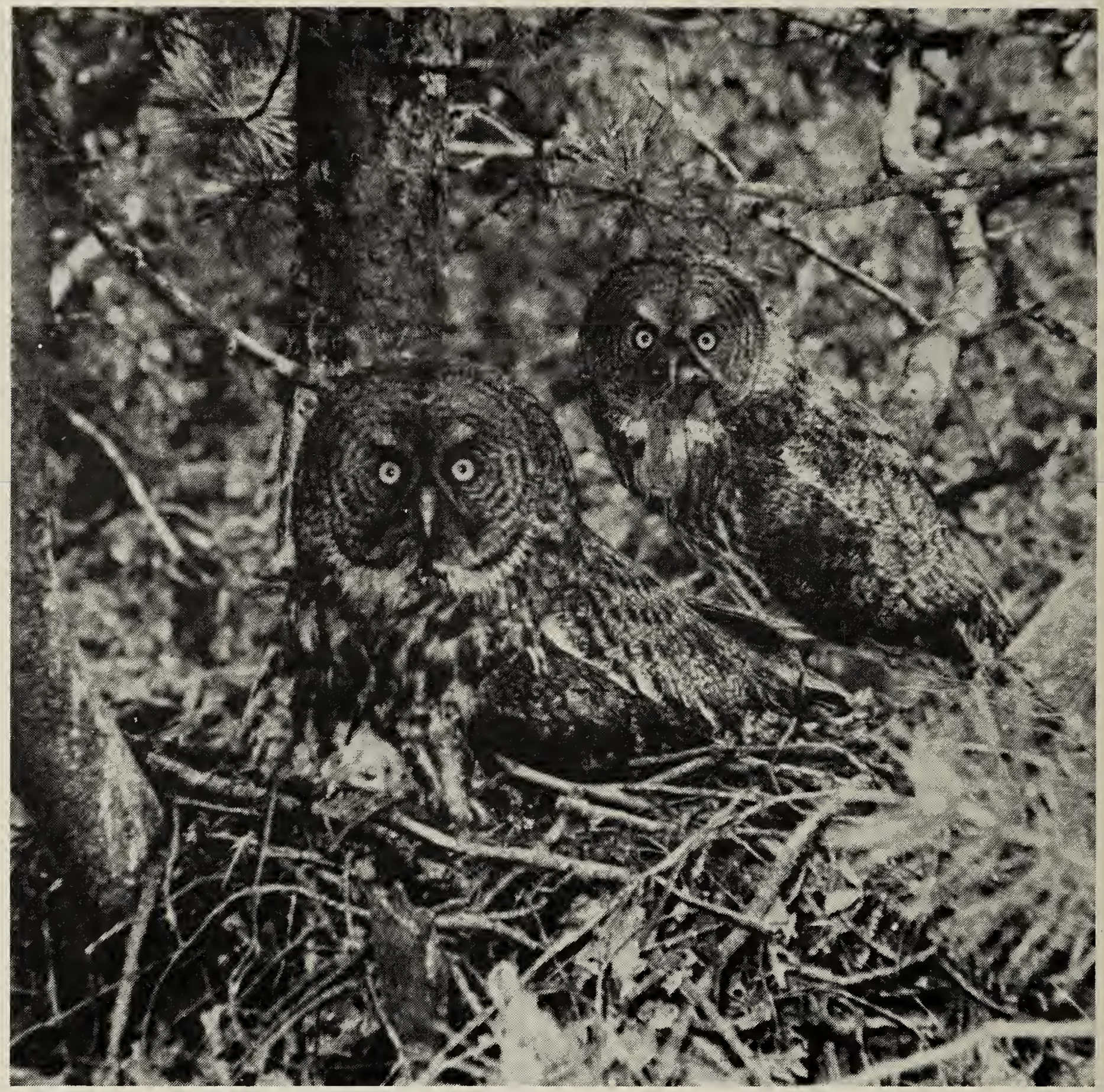

Two adult Great Gray Owls at nest.

Bob Gehlert

\title{
GREAT GRAY OWL AND WHIP-POOR-WILL IN PRINCE ALBERT NATIONAL PARK
}

DUANE SEPT, 16607-94 Avenue, Edmonton, Alta. T5R 5L4

During the summer of 1975 , I conducted a wildlife study for the Canadian Wildlife Service in Prince Albert National Park, Saskatchewan. Observations of two bird species are presented below.
Great Gray Owl: The Great Gray Owl is known to be an uncommon nester in Saskatchewan. To date, only two breeding records have been published. In 1937 an adult with young was located in an old Red-tailed Hawk's 
nest at the canyon on the Bainbridge River in the Pasquia Forest." The second record was located at Fort a la Corne Game Reserve in May, 1949.3

During the summer of 1975, a family of Great Gray Owls was observed on two separate occasions by the author. On both dates, July 24 and August 2, a single adult was observed feeding two fledglings, at Flat Creek, P.A.N.P. Ken Walker, a seasonal park naturalist, accompanied me on August 2. A third owlet may have been present on both occasions, but its presence was not verified. The fledglings were well developed and flew with little difficulty. Flat Creek is located in the southwest corner of the Park. Although the immediate vicinity of the creek is essentially boreal habitat, the area beyond is primarily aspen parkland.
Whip-Poor-Will: The northernmost record for the Whip-poor-will was Round Lake, Saskatchewan (just northwest of Prince Albert) in 1968. ${ }^{2}$ During the summer of 1975 , the unique song of the Whip-poor-will was heard at three separate locations. Table 1 summarizes all auditory observations.

These observations indicate that the Whip-poor-will is at present distributed as far north as Anglin Lake, P.A.N.P. This data probably represents a current range extension. It seems unlikely that this species has remained in the area undetected by several other investigators over several years (L. N. Carbyn, pers. comm.)

I would like to thank Anne Gunn and L. N. Carbyn for their kind assistance in this project.

TABLE 1

Location of singing Whip-Poor-Wills in the P.A.N.P.

Date

July 3,1975

July 5,1975

July 11,1975

July 12,1975

July 24,1975
Location

Rabbit Creek Cabin

Rabbit Creek Cabin

1.3 miles west of Sugar Creek

1.3 miles west of Sugar Creek

0.6 mile south of the Anglin Lake Dam
Time

Observers*

9:30 p.m.

A. G.

10:00 p.m.

A. G.

10:20 p.m.

A. G., L. C., D. S.

11:00 p.m.

D. S.

10:15 p.m.

D. S.

${ }^{*}$ Observers: A. G. (Anne Gunn), L. C. (L. N. Carbyn), D. S. (Duane Sept).

'GODFREY, W. E. 1966. The birds of Canada. Queens Printer Canada. $428 p$.

${ }^{2}$ HOUSTON, M. 1974. Interesting Prince Albert bird records. Blue Jay 32: 110-112.

"LAW, C. 1960. The Great Gray Owl of the woodlands. Blue Jay 18: 14-16.

${ }^{4}$ SOPER, J. D.. 1952. The birds of Prince Albert National Park. Saskatchewam. Wild Mgmt. Bull. Ser. 2, No. 4, Canadian Wildlife Service, Ot. tawa. $83 \mathrm{p}$.
5SYMONS, R. D. 1967. Hours and the birds, a Saskatchewan record. Univ. Toronto Press. $224 \mathrm{p}$. 